OPEN ACCESS

Edited by:

Tebello Nyokong,

Rhodes University, South Africa

Reviewed by:

Lukasz Sobotta

Poznan University of Medical

Sciences, Poland

Reama Chinedu George,

Obafemi Awolowo University, Nigeria

*Correspondence:

Edith K. Amuhaya eamuhaya@usiu.ac.ke

Specialty section:

This article was submitted to

Organic Chemistry,

a section of the journal

Frontiers in Chemistry

Received: 30 November 2020

Accepted: 15 February 2021

Published: 07 April 2021

Citation:

Oyim J, Omolo CA and Amuhaya EK (2021) Photodynamic Antimicrobial Chemotherapy: Advancements in

Porphyrin-Based

Photosensitize Development.

Front. Chem. 9:635344.

doi: 10.3389/fchem.2021.635344

\section{Photodynamic Antimicrobial Chemotherapy: Advancements in Porphyrin-Based Photosensitize Development}

\author{
James Oyim ${ }^{1,2}$, Calvin A. Omolo ${ }^{1,3}$ and Edith K. Amuhaya ${ }^{1 *}$ \\ ${ }^{1}$ School of Pharmacy and Health Sciences, United States International University-Africa, Nairobi, Kenya, ${ }^{2}$ Department of \\ Chemistry, University of Nairobi, Nairobi, Kenya, ${ }^{3}$ Discipline of Pharmaceutical Sciences, College of Health Sciences, University of \\ KwaZulu-Natal, Durban, South Africa
}

The reduction of available drugs with effectiveness against microbes is worsening with the current global crisis of antimicrobial resistance. This calls for innovative strategies for combating antimicrobial resistance. Photodynamic Antimicrobial Chemotherapy (PACT) is a relatively new method that utilizes the combined action of light, oxygen, and a photosensitizer to bring about the destruction of microorganisms. This technique has been found to be effective against a wide spectrum of microorganisms, including bacteria, viruses, and fungi. Of greater interest is their ability to destroy resistant strains of microorganisms and in effect help in combating the emergence of antimicrobial resistance. This manuscript reviews porphyrins and porphyrin-type photosensitizers that have been studied in the recent past with a focus on their structure-activity relationship.

Keywords: photodynamic antimicrobial chemotherapy, photosensitizers, antimicrobial resistance, porphyrins, microorganisms

\section{INTRODUCTION}

Infectious diseases continue to be one of the greatest healthcare challenges worldwide. The burden associated with these diseases remains high with the predominant diseases being tuberculosis, HIV/ AIDS, acute lower respiratory tract infections, diarrheal diseases, urinary tract infections, skin and soft tissue infections, infective endocarditis, and sepsis among others (Laxminarayan et al., 2020; Nicholson, 2020). The emergence of antimicrobial resistance (AMR) has further exacerbated the situation. A recent review by O'Neal forecasted that over 10 million deaths will be attributed to AMR by the year 2050 (O'Neill, 2014). Of these infectious diseases, bacterial infections play a significant role, with a high number of deaths worldwide associated with them. Since the launch of antibiotics more than 70 years ago, with the introduction of penicillin, antibiotics have contributed significantly to the decrease in morbidity and mortality rates associated with bacterial infections (Frieri et al., 2017). However, the increasingly rampant antibacterial resistance threatens to send us back to the pre-antibiotic era. Consequently, the WHO has recognized 'the fight against antimicrobial resistance' as a global priority that urgently requires newer treatment strategies (WHO, 2018; WHO, 2020).

One of the common denominators to AMR has been the use of conventional antimicrobial agents. These conventional agents have various limitations such as insufficient bacterial concentrations at the site of infections, exposure of healthy tissues and normal flora to the drug, poor adherence to prescribed regimens that require frequent administration, and various undesirable adverse events that have led to the development of bacterial resistance, consequently limiting the success of the treatment 


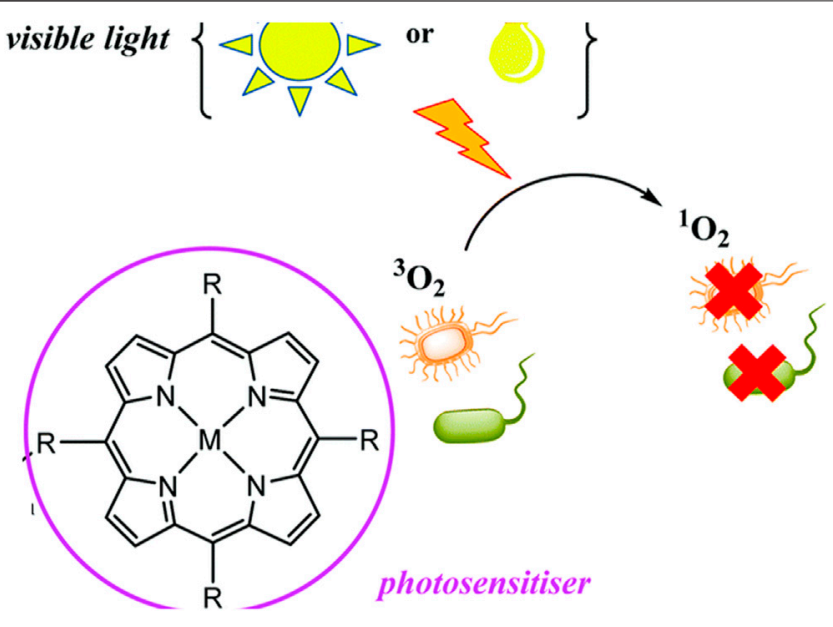

FIGURE 1 | Production of ROS by porphyrins and application in PACT. The illustration shows a generation of singlet oxygen upon irradiation by light which leads to microorganism destruction. Adapted with permission from Spagnul et al. (2017).

regimens (Omolo et al., 2018). The widespread misuse of antibiotics has also resulted in the growing problem of antimicrobial resistance in community and hospital settings (Rice, 2012). Moreover, most antimicrobial classes of antibiotics such as the $\beta$-lactams, glycopeptides, and fluoroquinolones have reportedly already developed resistance (Rice, 2012). Furthermore, most of the antimicrobial agents newly introduced to the market are modifications of the existing antimicrobial agents, and they thus lack a new mechanism of action (Theuretzbacher et al., 2020). Therefore, there is a need for a paradigm shift by introducing new agents that have novel mechanisms of action to fight AMR. This review summarizes the available research evidence on the use of porphyrin photosensitizers and their application in Photodynamic Antimicrobial Chemotherapy to eliminate disease-causing microbes. Additionally, the review will focus on structural modifications that have been made on porphyrins and delivery technologies that have been incorporated to further enhance their antimicrobial properties.

\section{PHOTODYNAMIC ANTIMICROBIAL CHEMOTHERAPY}

Photodynamic Antimicrobial Chemotherapy (PACT) is a promising strategy to eliminate pathogenic bacteria. Its mechanism of action occurs via the cytotoxic reactive oxygen species (ROS), which are generated by the photosensitive moieties after light irradiation. Upon absorption of light, the photosensitizer is excited to a higher excited singlet state. This is immediately followed by intersystem crossing of the excited photosensitizer to the excited triplet state. The electrons are then quenched by molecular oxygen to generate the toxic ROS, which is responsible for killing the microorganism. (Mai et al., 2017), (Coitiño et al., 2014). The ability of PACT to act on a wide range of bacteria, i.e., gram-negative and gram-positive, antibiotic-sensitive, and multi-resistant strains, presents a tremendous advantage that has made the technique gain a lot of research attention as an alternative strategy to combat antimicrobial resistance (Zeina et al., 2001; Sobotta et al., 2019). To date, various photosensitizers such as phenothiazines, acridines, phthalocyanines chlorins, and porphyrins have been studied for use as PACT photosensitizers (Skwor et al., 2016).

\section{Porphyrins in PACT}

Porphyrins and other tetrapyrrole molecules such as phthalocyanines and chlorins possess many desirable properties for use as photosensitizers in PACT. Key among these is their ability to absorb strongly in the UV-Vis near the IR region of the electromagnetic spectrum and their ability to generate a considerable triplet quantum yield, which makes them remarkable generators of ROS (Biscaglia and Gobbo, 2018; Nam et al., 2000) as shown in Figure 1. As a result, porphyrins have been found to have remarkable potential as antimicrobial agents (Vzorov et al., 2002).

\section{Finetuning Porphyrin-Based Photosensitizers Properties for PACT}

Porphyrins have a very flexible structure that can be modified in different ways to improve their photophysical and biological properties. This can be achieved through the insertion of different metals in the porphyrin's core or by selectively changing the peripheral substituents attached to the porphyrin skeleton at the meso, $\beta$-positions, or the porphyrin core (Beirão et al., 2014; Prasanth et al., 2014; Zoltan et al., 2015). Moreover, porphyrins have been reported to have very low bioavailability, a property that is attributed to their poor water solubility due to their hydrophobicity. Therefore, modifying their structures by adding polar substituents or by conjugating them with hydrophilic moieties such as amino acids, peptides, and proteins can lead to improved water solubility, which is an important property for their application in PACT (Figures 2-4).

As illustrated in Table 1, free porphyrins show potential for PACT application. Using various techniques that involve either complexation or covalent conjugations, various biomaterials have been employed in the modification of the physico-chemical and pharmacological properties of the attached porphyrin. For example, metals such as titanium dioxide $\left(\mathrm{TiO}_{2}\right)$ have been complexed with meso-tetrakis (p-sulfonatophenyl) porphyrin, and the resulting complexes showed improved photostability, fluorescence, and self-assembly into nanoparticles (Sułek et al., 2019). Another approach has involved the conjugation with amino acids, which added hydrophilicity and overall positive charge of the system. Conjugation with antimicrobial peptides (AMPs) and cell-penetrating peptides (CPPs) has also been reported. The use of AMPs and CPPs has led to an extended spectrum of activity, photostability, antimicrobial properties in the presence or absence of light, and the ability of the system to penetrate the cells and targeted organs (Dosselli et al., 2010). Other biomaterials also commonly used for fine-tuning the porphyrins are fatty acids. As shown in Table 1, fatty acids such as oleic acid and palmitic acid have been used to make superior porphyrin-based PACT systems. Such systems have exhibited better membrane penetration ability, enhanced microbial activity, reduction in aggregation of porphyrins, and high single oxygen production (Babu et al., 2019; Babu et al., 2020b). These 


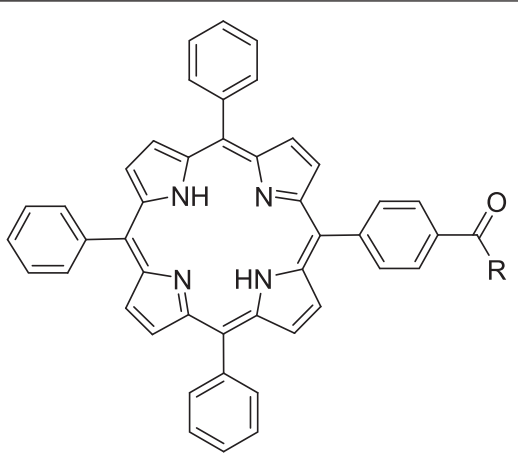

$1 b-d$<smiles>[R]C(=O)c1ccc(C2=C3C=CC(=N3)C(c3ccncc3)=C3C=CC(=N3)C(c3ccncc3)=C3C=CC(=N3)C(c3ccncc3)=C3C=CC(=N3)C2c2ccncc2)cc1</smiles>

$3 b-c$<smiles></smiles>

2a-c

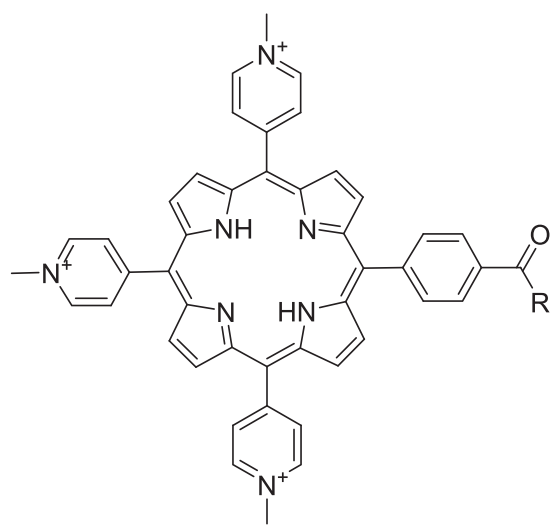

4b,e
a. $\mathrm{R}=-\mathrm{OCH} 3$
b. $\mathrm{R}=-\mathrm{OH}$
c. R= -Gly-Asn-Asn-Arg-Pro-Val-Tyr-Ile-Pro-GIn-Pro-Arg-Pro-Pro-His-Pro-His-Pro-Arg-Leu-OH
d. R= -Gly-Pro-Arg-Pro-Pro-His-Pro-Arg-Leu-OH
e. $\mathrm{R}=$ - Gly-Asn-Asn-Arg-Pro-Val-Tyr-Ile-Pro-GIn-Pro-Arg-Pro-Pro-His(N+CH3)-Pro-Arg-Leu-OH

FIGURE 2 | Conjugates obtained from the conjugation of porphyrins with antimicrobial peptides. There was enhanced PACT activity when the conjugates were used. By the use of the amide linkage, different peptides with different amino acid sequences and lengths were couped to the free porphyrins. The hydrophilicity offered by peptides together with the hydrophobicity of the peptides resulted in a conjugate that was amphophilic. The amphiphilicity results in better solubility of the free porphyrins Reproduced with permission from Dosselli et al. (2013).

modifications and the observed improvements are summarized in Table 1.

\section{ADVANCEMENT OF PORPHYRIN-BASED PHOTOSENSITIZERS FOR TARGETED ANTIMICROBIAL PHOTODYNAMIC THERAPY}

Recent advancements in synthetic chemistry and material science have resulted in the development of programable systems that respond to physiological changes due to diseases. PACT has followed a similar trend with the fabrication of systems that are stimuli-responsive to target bacteria. This section will focus on the advancement of porphyrin-based PACT systems for targeting bacteria and bacterial infection sites.

\section{Porphyrin-Based Photosensitizer Nanosystems}

The conjugation of porphyrins to nanoparticles has been explored. The conjugates have been found to exhibit enhanced antimicrobial properties and this is attributed to their biocompatibility and synergistic properties for PACT (Shabangu et al., 2020). By taking advantage of the small size of the porphyrins and porphyrin-nanoparticle conjugates, the photosensitizers can attach to the bacterial cell wall through a self-assembly process, resulting in 


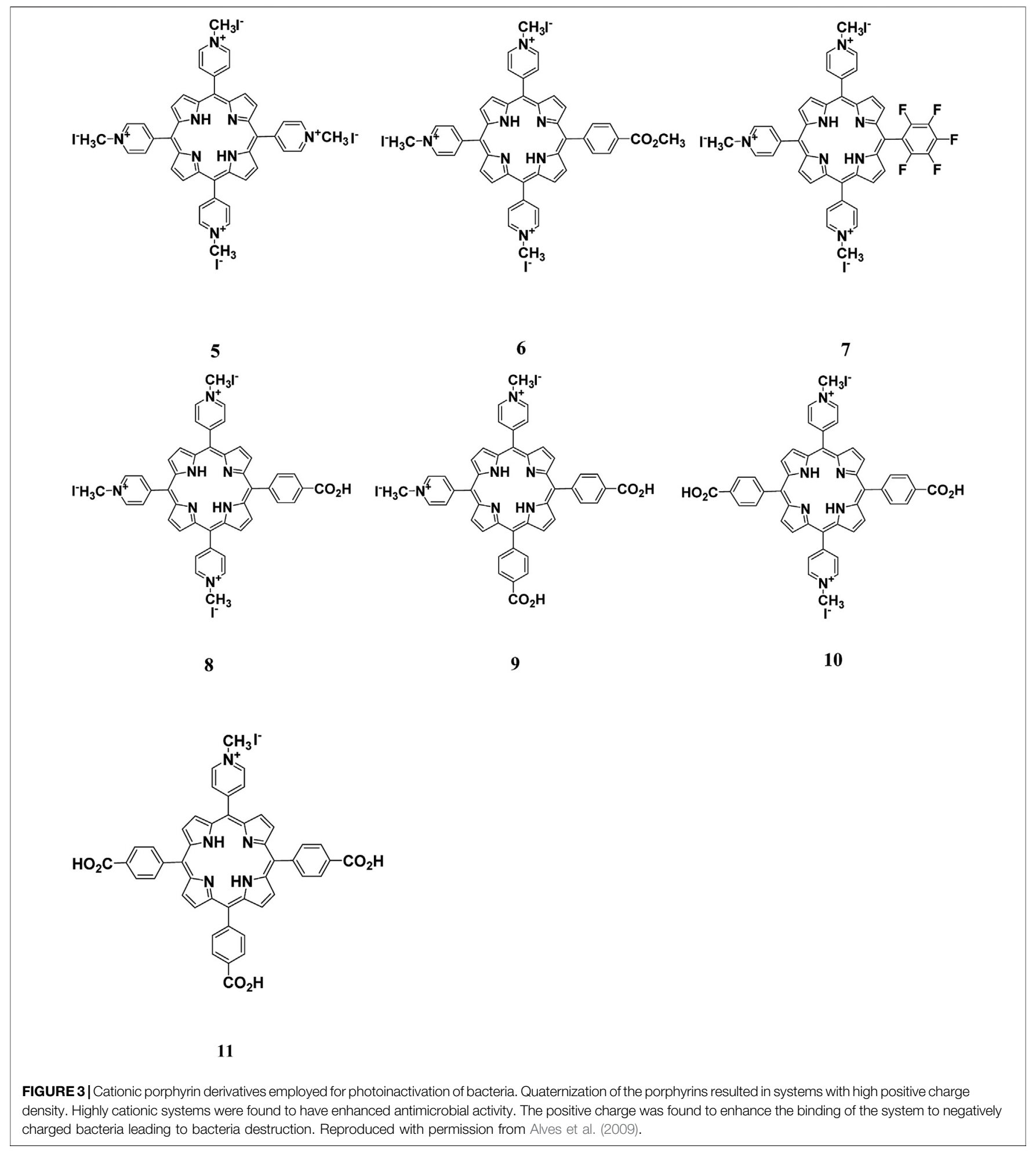

cell death. In some cases, however, these conjugations have led to unexpected interactions such as reduced uptake by the cells and reduced antimicrobial activity. (Wei et al., 2015; Kashef et al., 2017). The following sections will discuss various porphyrin-based nanoformulations.

\section{Self-Assembled Porphyrin-Based Photosensitizers}

Formulation of self-assembling photosensitizers has recently become a focus of interest in the field of photodynamic therapy with the synthesis of self-assembled porphyrin-based photosensitizers (SAPPs). SAPPs are synthesized by 


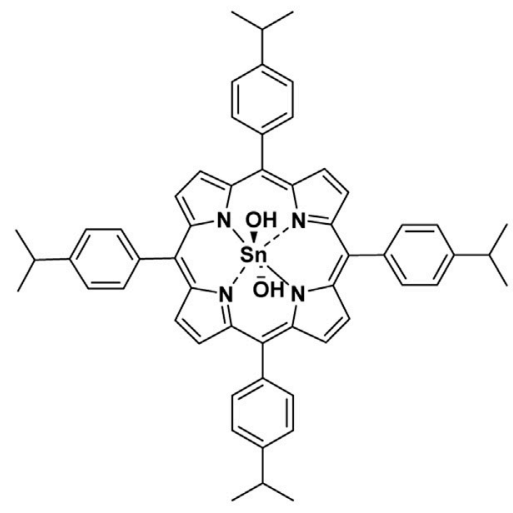

SnH (12)

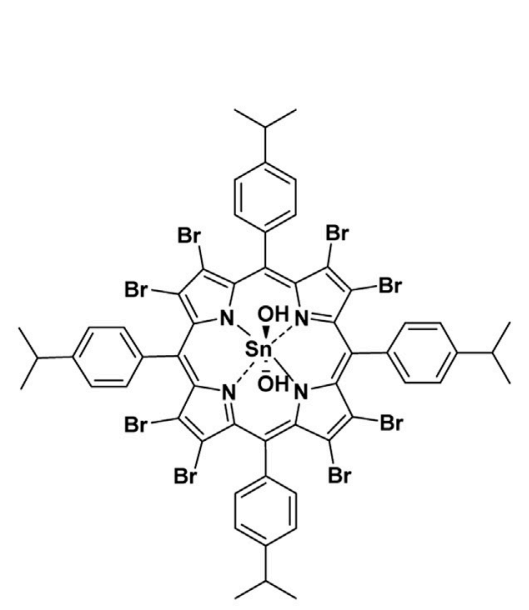

$\operatorname{SnBr}(13)$
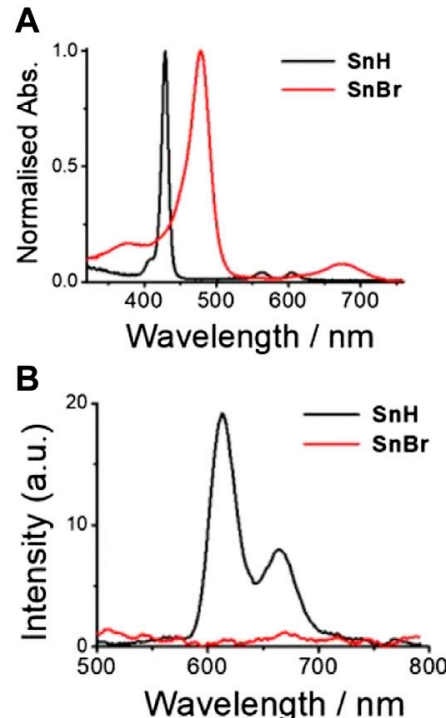

FIGURE 4 | (A) UV-Vis absorption (B) and emission spectra of porphyrins 12 and 13. These indicate the redshift in wavelength of absorption and quenching of the fluorescence upon bromination of the porphyrin. Reproduced with permission from porphyrin. Reproduced with permission from (Babu et al., 2020a).

conjugating hydrophobic porphyrins to hydrophilic or amphiphilic biomaterials such as polymers via covalent or supramolecular conjugations. These conjugations result in selfassembled nanostructures such as micelles (Spiller et al., 1998), polymersomes (Lanzilotto et al., 2018), honeycombs (Wang et al., 2014), nanofibers (Wang Q. et al., 2018), and metal-organic frameworks (MOFs) (Zhu et al., 2020). Electron spinresonance spectroscopy (ESR) studies have shown that selfassembled porphyrins generate high oxygen singlets that are extremely effective for Photodynamic Therapy (Wang D. et al., 2018). Using supramolecular chemistry, Özkan and co-workers synthesized SAPPs from cucurbit (Wang Q. et al., 2018) uril and porphyrin to form a multifunctional system. The system was found to efficiently eliminate broad-spectrum bacteria via a lighttrigger. To further potentiate the antibacterial activity, the system could be loaded effectively with drug molecules. As illustrated in Figure 5, the system was synthesized by conjugation of cucurbit (Omolo et al., 2018) uril shell, which acted as host for loaded drugs, to a free-base porphyrin core via suitable linkers (Kumar et al., 2019; Özkan et al., 2019). While the resulting system exhibited no dark activity towards E. coli (gram-negative bacteria), it showed relatively high cytotoxicity on $B$. subtilis (gram-positive bacteria). However, upon exposure to light, the self-assembled system had $100 \%$ bacteria elimination for both E. coli and B. subtilis. Similar SAPPs have been reported, with the systems showing improved PACT activities compared to the free porphyrins (Liu et al., 2013; Li et al., 2018; Khan et al., 2019).

\section{Dendrimer Based Porphyrin Photosensitizers}

Given that porphyrins are hydrophobic and have large $\pi$ conjugation domains, they usually exhibit aggregation which ultimately affects their photo functionalities. This disadvantage can be overcome by Dendrimer porphyrins (DPs) (Gerhardt et al., 2003). DPs have unique photo functional properties including large absorption surface area, increased fluorescence emission, and enhanced photosensitizing properties (Wirotius et al., 2013). DPs remain soluble in aqueous media as a result of the large number of anionic functional groups on their periphery, which arise from the dendrimer conjugations (Figure 6). Moreover, they have wedges that effectively prevent aggregation. Studies have shown that DPs have about 10-100fold higher photosensitizing effects when compared to bare protoporphyrin systems (Zhang et al., 2003). Penon and coworkers constructed a DP superstructure by coating the surface of the iron nanoparticles with two modified protoporphyrin molecules. From the study, it was found that DP with tris(hydroxymethyl)aminomethane (TRIS) modified protoporphyrin had two-fold singlet oxygen production ability when compared to the hydrophobic porphyrin system. It was concluded that hydrophilic systems were better for photodynamic therapy than hydrophobic ones (Penon et al., 2016). In another study, Staegemann and co-workers synthesized a high molecular dendritic mannose-functionalized hyperbranched polyglycerol and loaded it to a zinc porphyrin. The hydrophobic zinc (II) porphyrin photosensitizer was solubilized when it was loaded in the mannose- polyglycerol system. Further studies showed that an increased number of mannose molecules resulted in increased solubility of the zinc porphyrin, which led to better photosensitivity and consequently enhanced antibacterial activity (Staegemann et al., 2017). The increased photosensitivity and improved antimicrobial activity has been attributed to properties such as multivalence, an increased surface area to volume ratio, and an increased solubility that dendrimers have (Omolo et al., 2018).

\section{Liposomes Based Porphyrin Photosensitizers}

Liposomes are excellent vehicles for intracellular delivery as they easily fuse with biological membranes (Omolo et al., 2019). Ferro 
TABLE 1 | Porphyrin fine tuning and the resulting conjugate properties.

Type of porphyrins
5,10,15,20-tetrakis-(4-sulfonatophenyl)porphyrin
(TPPS); 5,10,15,20-tetrakis(2,6-difluoro-3-
sulfophenyl)porphyrin (F2POH), and 5,10,15,20-
tetrakis(2,6-difluoro-3-sulfophenyl)porphyrin Zn(II)
(ZnF2POH)

5-(4-nitrophenyl)-10,15,20-tripyridylporphyrin

5,10,15,20-Tetrakis(4-N-methylpyridyl)-

$21 \mathrm{H}, 23 \mathrm{H}$-porphyrin.

Nitrotetraphenylporphyrin used in modification

titanium dioxide $\left(\mathrm{qTiO}_{2}\right)$

Filter paper (cellulose) and cyanuric chloride as the linking agent

Polymyxin B

amino acids, I-lysine, I-histidine, and l-arginine,

2-hydroxypyridine axial ligated indium 5,10,15,20tetrakis-(4-phenylmethylthio) porphyrin (3) and quaternized 2-hydroxypyridine axial ligated indium 5,10,15,20-tetrakis-(4-phenylmethylthio) porphyrin tetrakis(N-methylpyridyl)porphyrin (TMPyP)

Tetrakis(4-carboxyphenyl) porphyrin (TCPP)

5(4'-carboxyphenyl)-10,15,20-triphenylporphyrin (cTPP)

tricationic porphyrin $[(5,10,15$-tris $(1-$ methylpyridinium-4-yl)-20-(pentafluorophenyl) porphyrin triiodide, Tri-Py+-Me-PF] Sn(IV) porphyrins

oleyamine and oleic acid (OLA)

Lysine Analogue of Polymyxin B

DNA

cationic antimicrobial peptide, apidaecin lb

1-palmitoyl-2-oleoyl-sn-glycero-3phosphatidylethanolamine pyridyloxyl transaxial ligand
Effect of modification

References

Stability of the resulting nanoparticles

Sułek et al. (2019)

Increase in the fluorescence when compared

to free Porphyrins

Increased levels of ROS generation after

impregnation of qTiO2

Multiple mechanisms of ROS generation

Exhibited antimicrobial activity at a very low

concentration

Broad-spectrum of activity

A strong photobactericidal effect against $S$.

aureus and E. coli.

Synergistic effect of Polymyxin B and PACT

Increased uptake by Fibroblasts thus

increasing wound healing.

Expanded spectrum of activity of Polymyxin

B to gram-positive bacteria after conjugation.

Amino acid conjugation resulted in water

solubility

Increased photostabilities

Increasing conjugation with lysine increased

production of singlet oxygen species

Better photoinactivation abilities of bacteria

when compared to the free Porphyrins

Conjugates were resistant to degradation in

serum within $24 \mathrm{~h}$.

Good biocompatibility

$8 \mathrm{log}$ reduction in bacteria

$100 \%$ bacteria elimination after 25 min

irradiation

Collen Makola et al. (2021)

4 log reduction compared to the untreated

control)

Mbakidi et al. (2013)

Le Guern et al.

(2017)

Meng et al. (2015)

Photobactericidal activity against Gram-

positive as well as Gram-negative bacteria

High ROS generation efficiency and

photostability

Improved killing efficiency of gram-positive S.

aureus bacteria

Increased water solubility

Broad spectrum of activity

Improved antibacterial activity when

compared to the free porphyrin

Improved antimicrobial effects and hence

broad-spectrum coverage against drug-

resistant strains of bacteria

Reduction in the aggregation of the

porphyrins

High singlet oxygen production

High killing efficacy against Staphylococcus

aureus and co-workers explored the positive traits of liposomes for intracellular delivery of two photosensitizing agents, hematoporphyrin and chlorophyll, for the elimination of Methicillin-resistant Staphylococcus aureus (MRSA) (Ferro et al., 2006). From the study, when loaded with hematoporphyrin, the liposome led to improved endocellular absorption of the photosensitizer compared to when the cells were incubated with the free porphyrin. The hematoporphyrinloaded liposome also displayed improved binding and more efficient photoinactivation of MRSA. Interestingly, hematoporphyrin did not affect the three-dimensional organization of the liposome during the photoinactivation of MRSA. On the other hand, chlorophyll markedly destroyed the structure of the lipid vesicle with no visible phototoxicity to MRSA. The same research group synthesized a positively charged meso-substituted porphyrin, (5-[4-(1-dodecanoylpyridinium)]-10,15,20-triphenyl-porphyrin) and delivered it via cationic liposomes for the elimination of MRSA. The free porphyrin had an unusually large fluorescence quantum yield (0.95), which led to the limited generation of singlet oxygen 


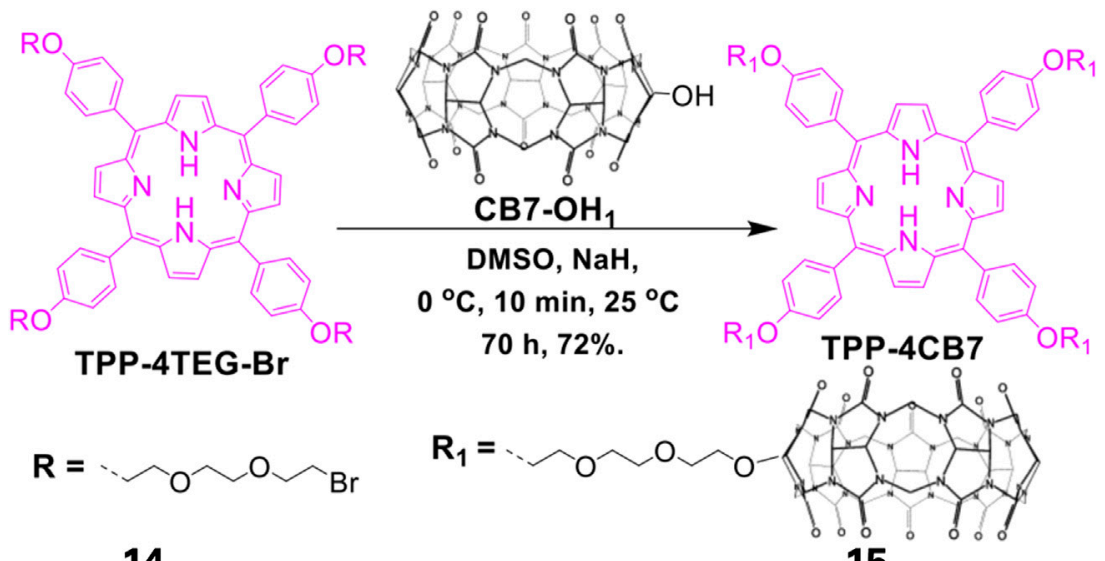

14

15

FIGURE 5| Synthesis of Cucurbit[7] uril-linked Porphyrin-based complex. The free TPP porphyrin was first conjugated to hydrophilic polyethylene glycol after which the resulting conjugate was complexed with that of Cucurbit[7]uril. This reaction resulted in a self-assembling amphiphilic system. Adapted with permission from Özkan et al. (2019).

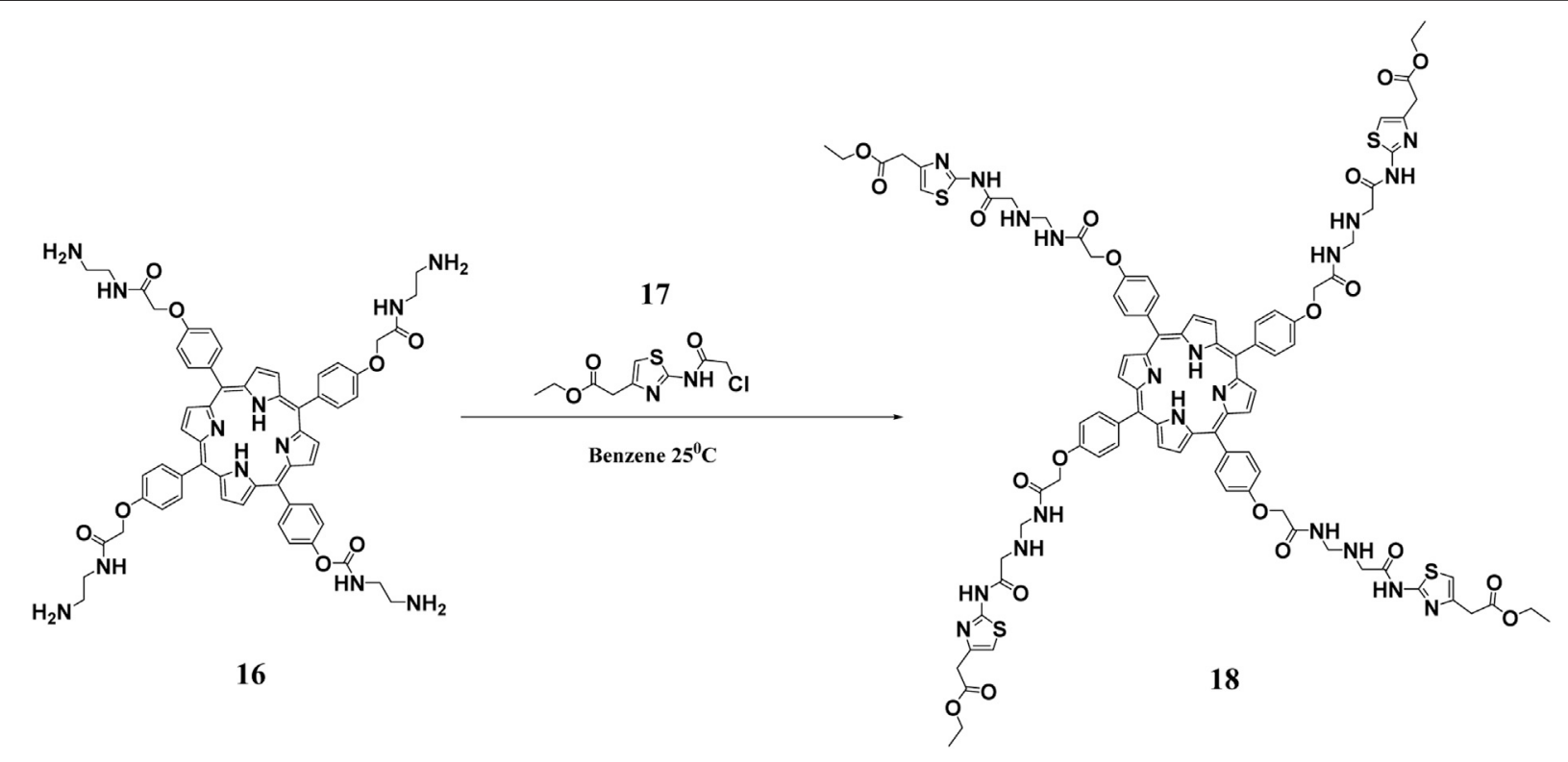

FIGURE 6 | Synthesis of hydrophilic DPs. This scheme shows the reaction of a polyamidoamine (PAMAM) functionalized porphyrin with ethyl 2-(2chloroacetamido)-4-thiazoleacetate to obtain the hydrophylic DP. Reproduced with permission from Hernández Ramírez et al. (2020).

(Ferro et al., 2007). The porphyrin displayed a relatively low photosensitizing activity against MRSA when dissolved in an aqueous solution or when incorporated into neutral liposomes. However, when the porphyrin was loaded to a cationic liposome, the phototoxicity effects against the bacteria increased remarkably. The increased effect upon loading the synthesized porphyrin in the cationic delivery system was attributed to the increased positive charge density (Hassan et al., 2020) that destroyed the bacterial wall, thereby enhancing the permeability of the photosensitizer. A similar study was reported by Bombelli and co-workers (Bombelli et al.,
2008). Moreover, high cationic charge density often has non-selective toxicity even to human cells (Fischer et al., 2003). Despite the good antimicrobial results, the study did not perform any cytotoxicity studies, and the application of the system on biotic systems will therefore be questionable.

\section{Other Nano Based Porphyrin Photosensitizers}

PACT has drawn the interest of nanotechnology as the efficacy of the treatment can be greatly augmented using nanoparticles. Nano-based porphyrin photosensitizers can be morphed into 
TABLE 2 | Different nanosystems for delivery of photosensitizers.

\begin{tabular}{|c|c|c|c|c|c|c|c|}
\hline Porphyrin used & Biomaterials & Nanocarrier & $\begin{array}{l}\text { Irradaiation } \\
\text { conditions }\end{array}$ & Bacteria tested on & Activity & Significant findings & References \\
\hline $\begin{array}{l}\text { 4-(15-(4-(2- } \\
\text { carboxyethyl)phenyl) } \\
\text { porphyrin-5-yl)-1- } \\
\text { methylpyridin-1-ium } \\
\text { lodide }\end{array}$ & Gelatin & $\begin{array}{l}\text { phototheranostic } \\
\text { polymeric } \\
\text { nanoparticle }\end{array}$ & $\begin{array}{l}\text { Green LED } \\
(0.5 \mathrm{~W}, \\
520-560 \mathrm{~nm}) \text { for } \\
\text { about } 3 \mathrm{~h}\end{array}$ & $\begin{array}{l}\text { Escherichia coli, } \\
\text { Serratia marcescens, } \\
\text { Pseudomonas } \\
\text { putida, Bacillus } \\
\text { subtilis, Candida } \\
\text { viswanathii }\end{array}$ & $\begin{array}{l}5 \text { and } 6 \text { log } \\
\text { antimicrobial } \\
\text { activity translating } \\
\text { to about } 99.999 \% \\
\text { elimination }\end{array}$ & $\begin{array}{l}\text { Excellent } \\
\text { hydrophilicity, } \\
\text { biocompatibility, and } \\
\text { stability, } \\
\text { High }{ }^{1} \mathrm{O}_{2} \text { quantum } \\
\text { yield ( } 44 \% \text { ), } \\
\text { High fluorescence } \\
\text { quantum yield (69\%) } \\
\text { Elimination of up } \\
\text { 99.9999\% of the } \\
\text { gram-negative and } \\
\text { positive bacteria and } \\
\text { fungus. }\end{array}$ & $\begin{array}{l}\text { Kirar et al. } \\
(2019)\end{array}$ \\
\hline $\begin{array}{l}\text { Hematoporphyrin } \\
\text { (HP) and Chlorophyll } \\
\text { a (Chlorin) }\end{array}$ & Cationic lipids & Liposomes & $\begin{array}{l}\text { White light from } \\
\text { a Teclas Lamp, } \\
100 \mathrm{~mW} / \mathrm{cm}^{2} \\
\text { For } 30 \mathrm{~min}\end{array}$ & MRSA & $\begin{array}{l}>5 \text { log inhibition of } \\
\text { MRSA by chlorin } \\
\text { alone in } 10 \text { min. } \\
\text { There was, } \\
\text { however, a } \\
\text { reduction in activity } \\
\text { when the delivery } \\
\text { systems were } \\
\text { applied For HP, the } \\
\text { delivery system } \\
\text { greatly enhanced } \\
\text { the inhibition } \\
\text { activity }\end{array}$ & $\begin{array}{l}\text { Endocellular } \\
\text { concentration of } \\
\text { photosensitizer } \\
\text { Elimination of MRSA }\end{array}$ & $\begin{array}{l}\text { Ferro et al. } \\
(2006)\end{array}$ \\
\hline $\begin{array}{l}\text { zinc meso-tetra (4- } \\
\text { pyridyl) porphyrin } \\
\text { (ZnTPyP) }\end{array}$ & $\begin{array}{l}\text { Zinc meso- } \\
\text { tetra (4-pyridyl) } \\
\text { porphyrin }\end{array}$ & $\begin{array}{l}\text { Cubic } \\
\text { nanoparticles }\end{array}$ & $\begin{array}{l}\text { Solar simulator } \\
\text { for } 120 \mathrm{~min}\end{array}$ & E. coli & $\begin{array}{l}50 \% \text { was } \\
\text { eliminated after } \\
30 \text { min. By } \\
120 \text { min, all the } \\
\text { E. Coli was } \\
\text { completely } \\
\text { eliminated }\end{array}$ & $\begin{array}{l}\text { Synthesized porphyrin } \\
\text { self-assembled into } \\
\text { cubic nanoparticles } \\
\text { High singlet oxygen } \\
\text { quantum yields } \\
\text { Fairly stable for a long } \\
\text { time in dark at ambient } \\
\text { conditions. Attractive } \\
\text { property for storage } \\
\text { and transportation. } \\
\text { Effective elimination of } \\
\text { bacteria }\end{array}$ & $\begin{array}{l}\text { Wang D. } \\
\text { et al. (2018) }\end{array}$ \\
\hline $\begin{array}{l}\text { Sinoporphyrin } \\
\text { sodium (DVDMS) }\end{array}$ & PLGA & Nanohybrids & $\begin{array}{l}\text { Different visible } \\
\text { laser doses }\end{array}$ & $\begin{array}{l}\text { Staphylococcus } \\
\text { aureus and } \\
\text { multidrug-resistant } \\
\text { (MDR) S. Aureus }\end{array}$ & $\begin{array}{l}\text { 4-log (99.9918\%) } \\
\text { inactivation of } \\
\text { MRSA and 5-log } \\
(99.9995 \%) \\
\text { inactivation of S. } \\
\text { aureus }\end{array}$ & $\begin{array}{l}\text { Eliminated } \\
\text { Staphylococcus } \\
\text { aureus and multidrug- } \\
\text { resistant (MDR) S. } \\
\text { Aureus } \\
\text { Accelerated wound } \\
\text { healing in a burn } \\
\text { infection model. } \\
\text { Increased several } \\
\text { regenerative factors. } \\
\text { Fluorescence imaging } \\
\text { achieved }\end{array}$ & $\begin{array}{l}\text { Mai et al. } \\
(2020)\end{array}$ \\
\hline $\begin{array}{l}\text { Tetrakis(4- } \\
\text { carboxyphenyl) } \\
\text { porphyrin }\end{array}$ & $\begin{array}{l}\text { Bimetallic } \\
\text { PCN-224(Zr/Ti) }\end{array}$ & $\begin{array}{l}\text { Metal-Organic } \\
\text { Framework }\end{array}$ & $\begin{array}{l}\text { Visible light } \\
\left(200 \mathrm{~mW} \mathrm{~cm}^{-2}\right) \\
\text { for } 3 \mathrm{~min}\end{array}$ & $\begin{array}{l}\text { S. aureus, S. } \\
\text { epidermidis, E. coli, A. } \\
\text { baumannii, MRSA, } \\
\text { MRSE, MDR E. coli } \\
\text { and MDR A. } \\
\text { baumannii }\end{array}$ & $\begin{array}{l}\text { 96.4\% MDR E. coli, } \\
\text { 96.8\% MRSA, and } \\
96.2 \% \text { MRSE were } \\
\text { eliminated }\end{array}$ & $\begin{array}{l}\text { Elimination of } \\
\text { multidrug-resistant } \\
\text { bacteria } \\
\text { High singlet oxygen } \\
\text { quantum yields } \\
\text { Accelerated wound } \\
\text { healing }\end{array}$ & $\begin{array}{l}\text { Chen et al. } \\
\text { (2020) }\end{array}$ \\
\hline
\end{tabular}

various nanosystems. One of the applications of the nanosystems is the improvement in the delivery of a photosensitizer to the bacteria and fluorescence inactivation kinetics. Nanosystems such as polymeric nanoparticles have been loaded with porphyrins to enhance the delivery to microorganisms and improve PACT activity. The polymeric nanosystems in focus have been on systems coined from biocompatible and biodegradable polymers such as from polylactic glycolic acid (PLGA) (Mai 
et al., 2020), poly(ع-caprolactone) (PCL) (Liu et al., 2017; Kubát et al., 2019; Chen et al., 2020; Contreras et al., 2020), gelatin (Kirar et al., 2019), and cyclodextrins (Ferro et al., 2009; Castriciano et al., 2017; Khurana et al., 2019; Zagami et al., 2020). Several reports of many nanosystems for PACT have been reported with great success as shown in Table 2.

Table 2 summarizes the improvements in the physicochemical and pharmacological properties of PACT systems when porphyrins are incorporated in nanocarriers. Different porphyrins have been incorporated in various nanosystems, such as liposomes, cubosomes, nanohybrids, and metal organic frameworks (MOF), to form multifunctional systems. For example, the combination of the porphyrins with biomaterials has resulted in systems that can be employed for theranostic purposes and PACT (Kirar et al., 2019). The porphyrin-based nanoformulations have also been reported to have controlled release and distribution properties for the singlet oxygen species and enhanced absorption in targeted cells and organs.

\section{Multifunctional Porphyrin Based Systems}

The advancement of synthetic chemistry and material science has resulted in the development of various multifunctional porphyrinbased systems. These include systems such as theranostic, woundhealing, and antimicrobial systems that have been reported in literature. Mai and co-workers reported a multifunctional porphyrin loaded nanosystem that was employed in the treatment of burn infections, stimulation of wound healing, elimination of a wide spectrum of bacterial via PACT, and bioimaging (Figure 7) The system was composed of the porphyrin photosensitizer, sinoporphyrin sodium (DVDMS), and poly(lactic-co-glycolic acid) (PLGA) was encapsulated with basic fibroblast growth factor (bFGF) and formed nanospheres. The nanospheres were implanted in a carboxymethyl chitosan (CMCS)-sodium alginate hybrid hydrogel. The system was evaluated for antibacterial properties against multidrug resistance bacteria (MDR), rheological properties, fluorescence imaging, and biocompatibility. The results indicated that the system had a $99.99 \%$ elimination of $S$. aureus and MDR $S$. aureus in mice models. Moreover, the nanosystem exhibited enhanced wound healing and regulation of regenerative and proinflammatory factors (Figure 8) (Mai et al., 2020). Another multifunctional porphyrin system was reported by Dai and co-workers. Their system was a thermosensitive and photosensitive micelle that was formulated from a star polymer, poly( $\varepsilon$ caprolactone)-block-Poly( $N$-isopropylacrylamide), which had a porphyrin-core (Dai et al., 2014). The system showed potential for multifunctionality and application. However, further characterization of the system is needed. Other multi-functional porphyrin-based systems, with antimicrobial and cancer therapy applications, have been reported in the literature (Belali et al., 2017; Cao-Milán et al., 2020; Li et al., 2020).

\section{IN VIVO APPLICATIONS OF PACT BASED ON PORPHYRINS}

In vivo studies are paramount to evaluate the translational ability of the formulated system to human trials. PACT systems have been gaining momentum as a treatment. The possible evaluation of clinical applications of PACT has included treatment of wound infections, body cavity infections (such as the mouth, nasal sinuses, and ear), and surface infections of the skin and cornea. This section will evaluate the various application of PACT systems in animal models.

\section{PACT in Treatment of Wounds and Acceleration of Wound Healing}

The effects of PACT on the treatment of skin infections have mostly been demonstrated in in vitro studies. What is still lacking is a complete in vivo evaluation of the feasibility of PACT in treating skin and soft-tissue infections. Many researchers have in recent times discouraged the over-reliance on in vitro studies results in PACT because of the variations of outcomes encountered when carrying out the complementary in vivo studies. This means that conducting in vivo follow-up studies, right after an in vitro study, is key in establishing the overall efficacy of PACT.

In vivo studies were carried out by Fila and co-workers where they utilized four photosensitizers in a murine model with chronic wounds that were infected with Pseudomonas aeruginosa and MRSA. While comparing the in vivo results with their past in vitro findings, they observed that there was a considerable reduction of the effectiveness of the therapy in vivo. The photosensitizers, 5,10,15,20-tetrakis(1-methyl pyridinium-4-yl) porphyrin (TMPyP), Rose Bengal, $\left[\mathrm{Ru}\left(2,2^{\prime}\right.\right.$-bipyridine $) 2\left(2-\left(2^{\prime}, 2^{\prime \prime}\right.\right.$ : $5^{\prime \prime}, 2^{\prime \prime \prime}$-terthiophene)-imidazo[4,5-f][1,10] phenanthroline) $] 2+$ (TLD-1411), and methylene blue demonstrated good antimicrobial efficacy in 1-50 $\mu \mathrm{M}$ planktonic solutions; however, in in-vivo, there was a $24-48 \mathrm{~h}$ growth delay for MRSA and an extended growth inhibition of $P$. aeruginosa by the TLD-1411assisted photodynamic therapy. In the in vitro studies, a $6 \log _{10}$ reduction was attained even with the least concentration of $1 \mathrm{mM}$. However, in the in vivo tests, none of the photosensitizers achieved sterilization that was even equivalent to $3 \log _{10}$ reduction based on bioluminescence radiance measurement (Fila et al., 2016).

Nonetheless, completely different observations have been made in other studies with better outcomes emerging during in vivo studies. For instance, $\mathrm{Xu}$ and co-workers (2016) studied the wound healing effect of PACT on mixed bacterial infections in rats using the lysin conjugate of 5,10,15,20tetrakis(1-methyl pyridinium-4-yl)porphyrin tetra-iodide. Their studies demonstrated that the porphyrin was highly potent both in vitro and in vivo. It was also observed that the applied dose of light was a key factor for the success of PACT. In this study, a light dose of $50 \mathrm{~J} / \mathrm{cm}^{2}$ was established as the most suitable (Xu et al., 2016). A similar study done by Yuan and co-workers (Yuan et al., 2017) found that the cationic lysine-porphyrin conjugate (12) accelerated wound healing, while the cytotoxicity test conducted in mice showed that the porphyrin was not toxic.

The effectiveness of PACT in treating infected wounds has also been recently studied by Zhao and co-workers using a protoporphyrin IX-ethylenediamine derivative (13) against Pseudomonas aeruginosa in an in vivo model of $P$. aeruginosa-infected wounds. Their study 


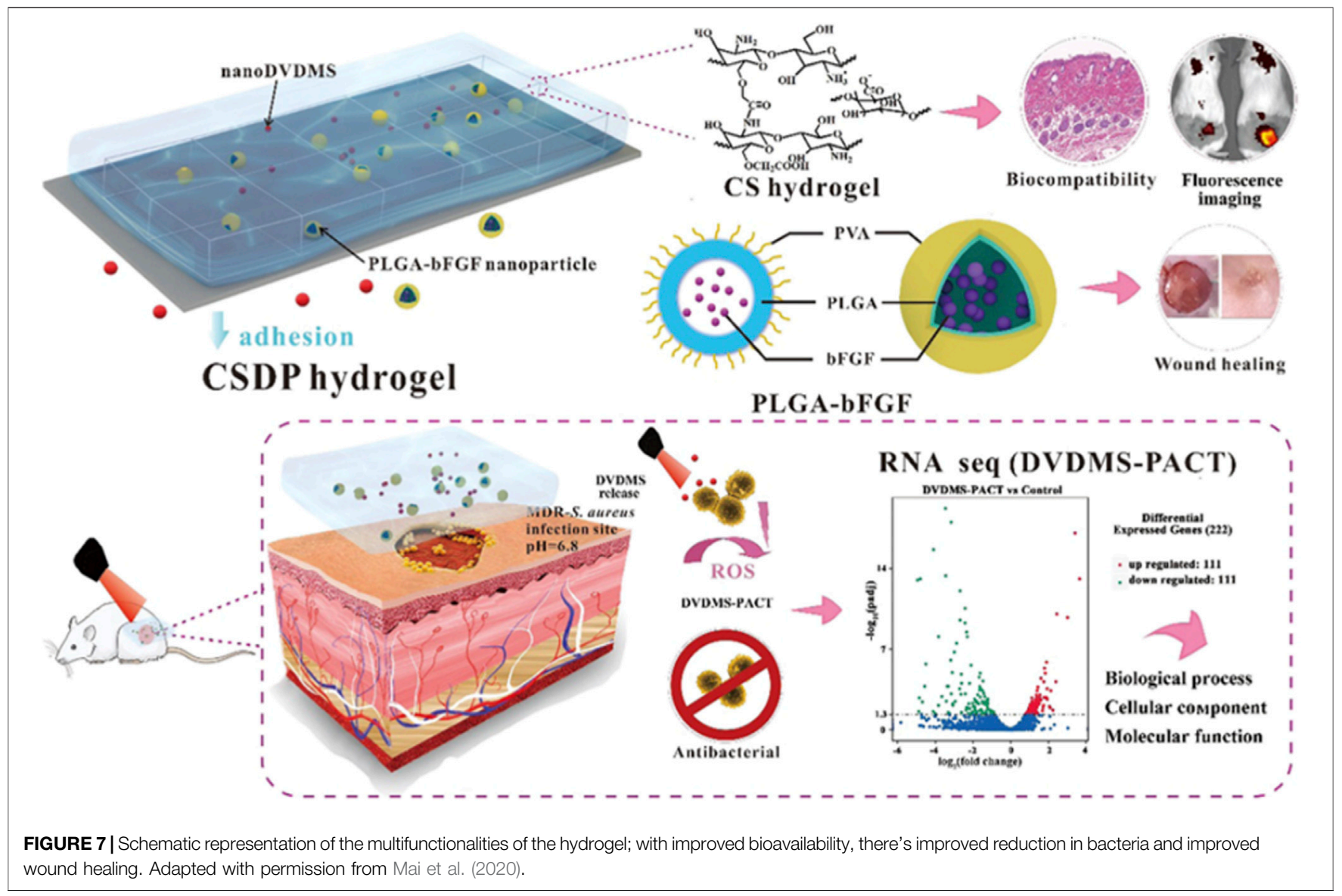

showed a significant reduction of the number of $P$. aeruginosa colonies. Additionally, the histological analysis demonstrated a very high wound healing rate (98\%) after 14 days of therapy (Figure 9). According to the findings, $100 \mu \mathrm{M}$ concentration of the porphyrin resulted in a $4.2 \log _{10}$ reduction of $P$. aeruginosa colony units, which translated to about $10 \%$ more activity compared to the control group (Zhao et al., 2020).

\section{PACT in Treatment of Body Cavity Infections}

In vivo studies on the effects of PACT in oral fungal infections commonly caused by C. albicans were studied by Mima and coworkers. The group used Photogene (hematoporphyrin derivative) and two light sources-blue $(455 \mathrm{~nm})$ and red $(630 \mathrm{~nm})$ - to carry out their studies. From their results, there was a significant reduction in C. albicans obtained from the tongues of mice. The results from the histological evaluation showed that the local mucosa was not adversely affected by PACT (Mima et al., 2010). In a study by de Santi and co-workers (2018), PACT was also found to be effective against yeast cells that cause vaginal candidiasis. Utilizing protoporphyrin IX, among other photosensitizers, there was a significantly reduced C. albicans population, which was accompanied by prevention of further re-infection for about 1 week (de Santi et al., 2018). The results of these studies show alternative treatment of fungal infections by PACT is not only feasible but also safe.

Researchers have in the recent past explored various treatment methods including the effectiveness of PACT in the treatment of periodontitis (Moreira et al., 2015; Stájer et al., 2020). For instance, Prasanth and co-workers synthesized pyridinium-substituted porphyrin derivative 14 and meso-imidazolium-substituted porphyrin derivative $\mathbf{1 5}$ and studied their activity. The derivatives not only showed complete penetration into biofilms but also displayed better efficacy against the oral pathogens associated with periodontitis such as F. nucleatum, E. faecalis, and A. actinomycetemcomitans (Prasanth et al., 2014).

With most studies focusing on in vitro evaluation, an in vivo study was successfully carried out by Sigusch and coworkers using the beagle dog model. From this study, they observed that photodynamic therapy using chlorine e6 and $662 \mathrm{~nm}$ laser light source resulted in significant suppression of $P$. gingivalis and there was an overall reduction of the periodontal signs of redness and bleeding on probing (Sigusch et al., 2005). To experiment on human models, a full-mouth PACT in F.nucleatum-infected patients was carried out. The study established that the adjuvant application PACT method was effective in reducing periodontal inflammatory symptoms and treatment of $F$. nucleatum (Sigusch et al., 2010). 


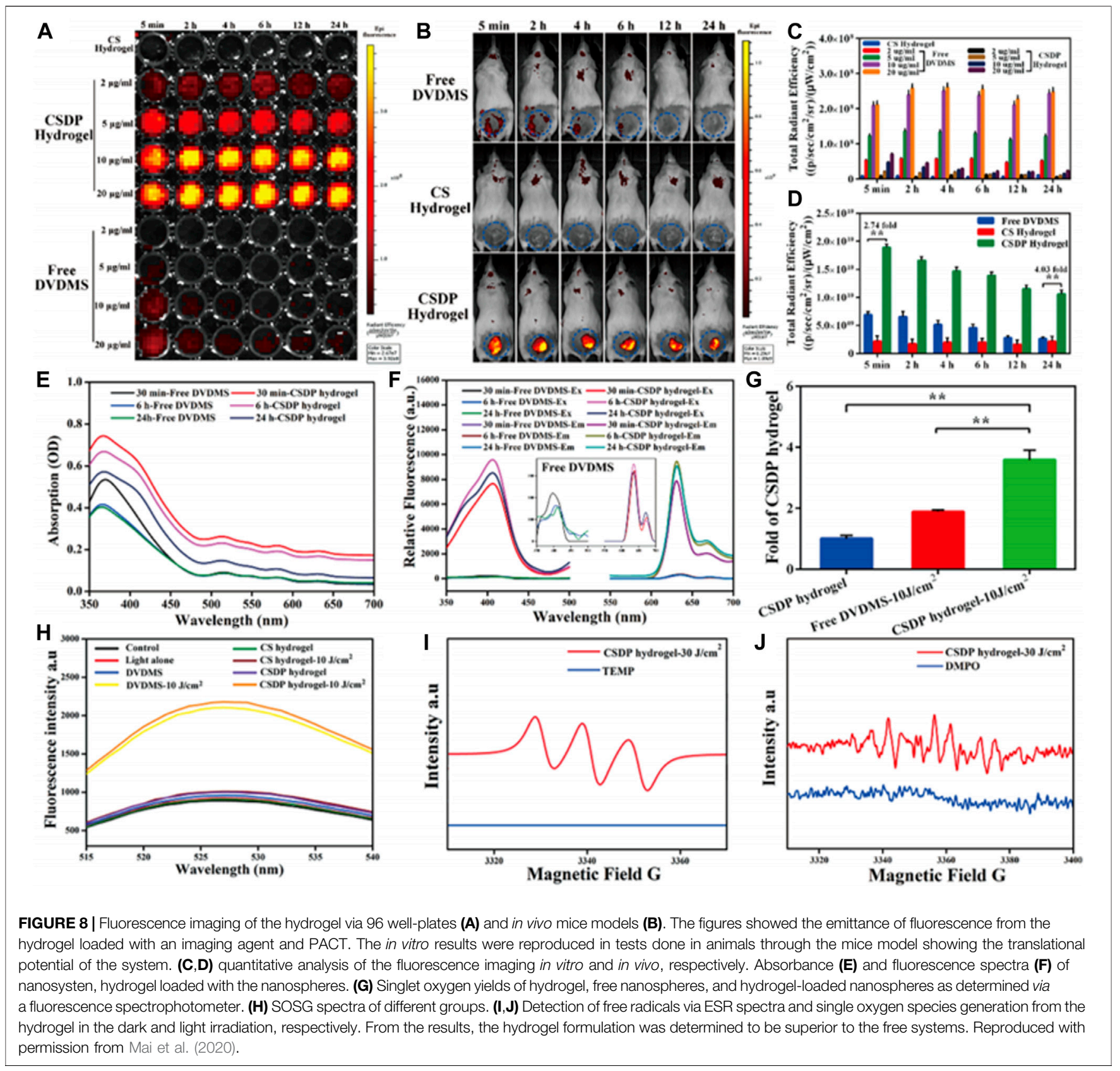

\section{FUTURE PERSPECTIVES}

As we have described in this review, porphyrins and their use in PACT continue to draw a lot of attention, with novel porphyrins and porphyrin conjugates being continuously synthesized. Indeed, the possibilities are unlimited. With the development of many different porphyrin synthetic routes coupled with their flexibility for modifications and conjugations to different moieties, more superior porphyrins can be designed and synthesized as the search for more efficient antibacterial agents for use in PACT are developed.

Much more still needs to be done in the application of PACT in dermatological and control of infectious diseases, especially in the management of acne and skin infections in general. Given the wide range of bacteria, it has been noted that the potential application of PACT in the treatment of infectious diseases is still lagging even with the positive acceptance of photodynamic therapy in treatment for other diseases such as psoriasis and skin cancers. There is, therefore, a need for researchers to further explore this application.

While the application of the PACT systems has been extensively evaluated for topical/local approach for animal model evaluations, more studies on systemic application still need to be done to fully evaluate their in vivo stability and therapeutic modality. It is important to fully understand their mechanisms of action and fine-tune them appropriately to improve their sensitivity and 

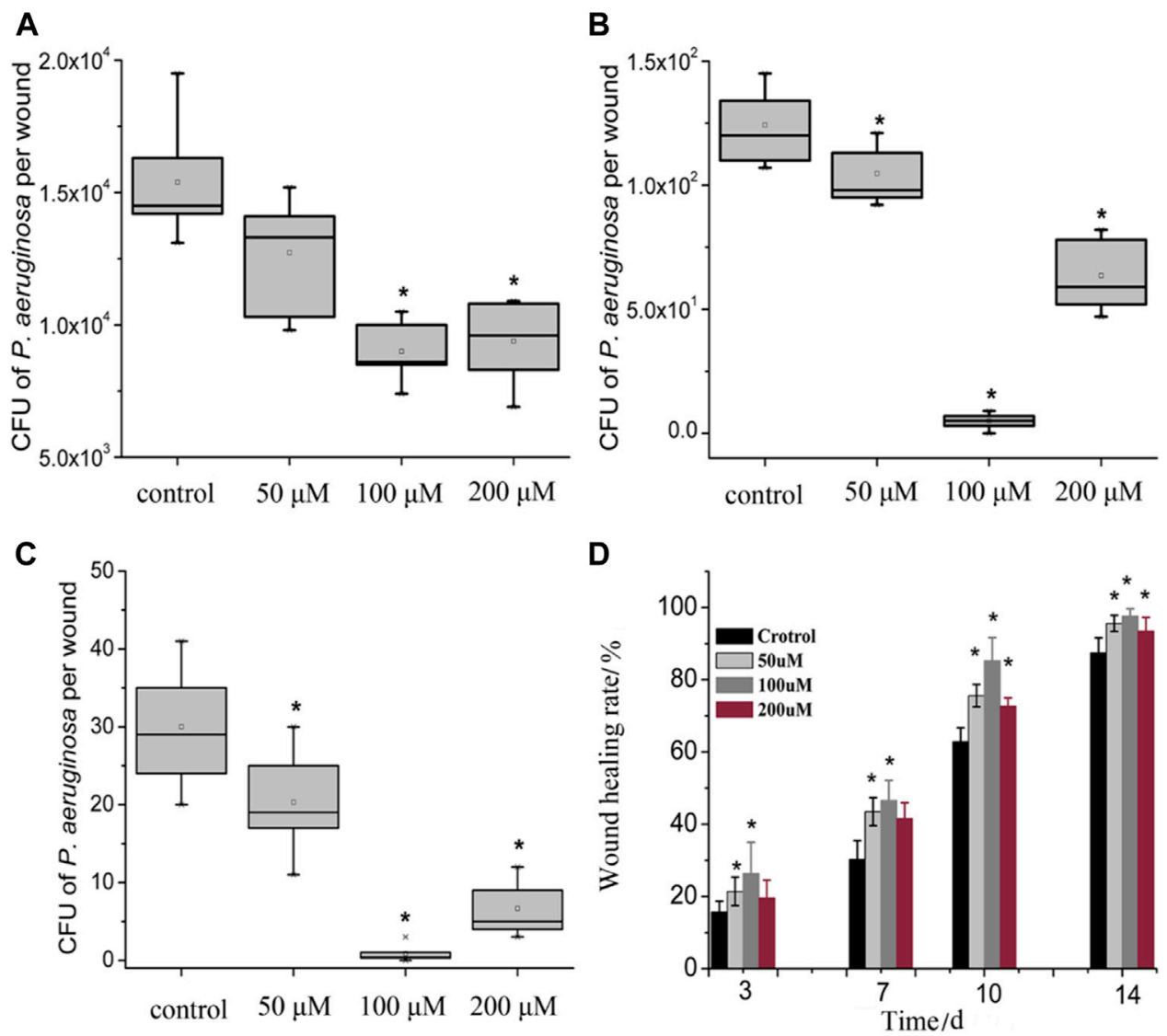

FIGURE 9 | Box plot of the viability of bacteria in wounded tissue in. Wound healing rate in the PACT chemotherapy groups when compared control groups on evaluated at different days. (A-C) showed there was a dose-dependent reduction of the CFU recovered from the wounds in various treatment groups when compared to the control. Treatment groups receiving $100 \mu \mathrm{M}$ showed the best antimicrobial activity. (D) showed that the healing percentage correlated to the reduction of CFUs illustrated in (A-C). A reduction in CFU recovered was accompanied by an increase in wound healing percentage. Reproduced with permission from Zhao et al. (2020).

selectivity. Notably, most studies discussed in this mini-review lacked toxicity data, and there is a need, therefore, for future studies to carry out toxicity studies (either short term or long term). This is very important because toxicity profile evaluation will go along way to bringing confidence in PACT systems before submitting the final products to regulatory endorsements.

Despite the gaps, the reported studies in this review indicate that there is a possibility of adding PACT systems to the current therapeutic arsenals for combating microbial resistance, especially where the conventional antimicrobials have failed. We believe that as the field of PACT continues to grow, the

\section{REFERENCES}

Alves, E., Costa, L., Carvalho, C. M., Tomé, J. P., Faustino, M. A., Neves, M. G., et al. (2009). Charge effect on the photoinactivation of Gram-negative and grampositive bacteria by cationic meso-substituted porphyrins. BMC Microbiol. 9 (1), 70. doi:10.1186/1471-2180-9-70

Alves, E., Santos, N., Melo, T., Maciel, E., Dória, M. L., Faustino, M. A. F., et al. (2013). Photodynamic oxidation of Escherichia coli membrane phospholipids: development of even more robust photosensitizers is more likely, based on the improved understanding of the specific action mechanisms and disease targeting ability of the developed systems. Such changes will lead to an increased role of PACT in the management of microbial infections.

\section{AUTHOR CONTRIBUTIONS}

$\mathrm{JO}, \mathrm{CO}$, and EA conceptualized the idea and contributed to the writing of the article.

new insights based on lipidomics. Rapid Commun. Mass Spectrom. 27 (23), 2717-2728. doi:10.1002/rcm.6739

Babu, B., Amuhaya, E., Oluwole, D., Prinsloo, E., Mack, J., and Nyokong, T. (2019). Preparation of NIR absorbing axial substituted tin(iv) porphyrins and their photocytotoxic properties. MedChemComm 10 (1), 41-48. doi:10.1039/c8md00373d

Babu, B., Mack, J., and Nyokong, T. (2020a). An octabrominated Sn(iv) tetraisopropylporphyrin as a photosensitizer dye for singlet oxygen biomedical applications. Dalton Trans. 49 (28), 9568-9573. doi:10.1039/ d0dt01915a 
Babu, B., Soy, R. C., Mack, J., and Nyokong, T. (2020b). Non-aggregated lipophilic water-soluble tin porphyrins as photosensitizers for photodynamic therapy and photodynamic antimicrobial chemotherapy. New J. Chem. 44 (26), 11006-11012. doi:10.1039/d0nj01564d

Beirão, S., Fernandes, S., Coelho, J., Faustino, M. A. F., Tomé, J. P. C., Neves, M. G. P. M. S., et al. (2014). Photodynamic inactivation of bacterial and yeast biofilms with a cationic porphyrin. Photochem. Photobiol. 90 (6), 1387-1396. doi:10. 1111/php.12331

Belali, S., Karimi, A. R., and Hadizadeh, M. (2017). Novel nanostructured smart, photodynamic hydrogels based on poly( $\mathrm{N}$-isopropylacrylamide) bearing porphyrin units in their crosslink chains: a potential sensitizer system in cancer therapy. Polymer 109, 93-105. doi:10.1016/j.polymer.2016.12.041

Biscaglia, F., and Gobbo, M. (2018). Porphyrin-peptide conjugates in biomedical applications. J. Pept. Sci. 110 (5), e24038. doi:10.1002/pep2.24038

Bombelli, C., Bordi, F., Ferro, S., Giansanti, L., Jori, G., Mancini, G., et al. (2008). New cationic liposomes as vehicles of m-tetrahydroxyphenylchlorin in photodynamic therapy of infectious diseases. Mol. Pharm. 5 (4), 672-679. doi: $10.1021 / \mathrm{mp} 800037 \mathrm{~d}$

Cao-Milán, R., Gopalakrishnan, S., He, L. D., Huang, R., Wang, L. S., Castellanos, L., et al. (2020). Thermally gated bio-orthogonal nanozymes with supramolecularly confined porphyrin catalysts for antimicrobial uses. Chem 6, 1113-1124. doi:10.1016/j.chempr.2020.01.015

Castriciano, M. A., Zagami, R., Casaletto, M. P., Martel, B., Trapani, M., Romeo, A., et al. (2017). Poly(carboxylic acid)-cyclodextrin/anionic porphyrin finished fabrics as photosensitizer releasers for antimicrobial photodynamic therapy. Biomacromolecules 18 (4), 1134-1144. doi:10.1021/acs.biomac.6b01752

Chen, M., Long, Z., Dong, R., Wang, L., Zhang, J., Li, S., et al. (2020). Titanium incorporation into Zr-porphyrinic metal-organic frameworks with enhanced antibacterial activity against multidrug-resistant pathogens. Small 16 (7), 1906240. doi:10.1002/smll.201906240

Coitiño, E. L. M., Mella, A., and Cárdenas-Jirón, G. I. (2014). Theoretical assessment of the photosensitization mechanisms of porphyrinruthenium(II) complexes for the formation of reactive oxygen species. J. Photochem. Photobiol. A 294, 68-74. doi:10.1016/j.jphotochem.2014.08.003

Collen Makola, L., Nyokong, T., and Amuhaya, E. K. (2021). Impact of axial ligation on photophysical and photodynamic antimicrobial properties of indium (III) methylsulfanylphenyl porphyrin complexes linked to silvercapped copper ferrite magnetic nanoparticles. Polyhedron 193, 114882. doi:10.1016/j.poly.2020.114882

Contreras, A., Raxworthy, M. J., Wood, S., and Tronci, G. (2020). Hydrolytic degradability, cell tolerance and on-demand antibacterial effect of electrospun photodynamically active fibres. Pharmaceutics 12 (8), 711. doi:10.3390/ pharmaceutics 12080711

Dai, X.-H., Jin, H., Yuan, S. S., Pan, J. M., Wang, X. H., Yan, Y. S., et al. (2014). Synthesis and characterization of thermosensitive, star-shaped poly $(\varepsilon-$ caprolactone)-block-Poly(N-isopropylacrylamide) with porphyrin-core for photodynamic therapy. J. Polym. Res. 21 (6), 412. doi:10.1007/s10965-0140412-9

de Santi, M. E. S. O., Prates, R. A., França, C. M., Lopes, R. G., Sousa, A. S., Ferreira, L. R., et al. (2018). Antimicrobial photodynamic therapy as a new approach for the treatment of vulvovaginal candidiasis: preliminary results. Lasers Med. Sci. 33 (9), 1925-1931. doi:10.1007/s10103-018-2557-y

Dosselli, R., Gobbo, M., Bolognini, E., Campestrini, S., and Reddi, E. (2010). Porphyrin-apidaecin conjugate as a new broad spectrum antibacterial agent. ACS Med. Chem. Lett. 1 (1), 35-38. doi:10.1021/ml900021y

Dosselli, R., Tampieri, C., Ruiz-González, R., De Munari, S., Ragàs, X., SánchezGarcía, D., et al. (2013). Synthesis, characterization, and photoinduced antibacterial activity of porphyrin-type photosensitizers conjugated to the antimicrobial peptide apidaecin 1b. J. Med. Chem. 56 (3), 1052-1063. doi: $10.1021 / \mathrm{jm} 301509 \mathrm{n}$

Ferro, S., Jori, G., Sortino, S., Stancanelli, R., Nikolov, P., Tognon, G., et al. (2009). Inclusion of 5-[4-(1-dodecanoylpyridinium)]-10,15,20-triphenylporphine in supramolecular aggregates of cationic amphiphilic cyclodextrins: physicochemical characterization of the complexes and strengthening of the antimicrobial photosensitizing activity. Biomacromolecules 10 (9), 2592-2600. doi:10.1021/bm900533r

Ferro, S., Ricchelli, F., Mancini, G., Tognon, G., and Jori, G. (2006). Inactivation of methicillin-resistant Staphylococcus aureus (MRSA) by liposome-delivered photosensitising agents. J. Photochem. Photobiol. B, Biol. 83 (2), 98-104. doi:10.1016/j.jphotobiol.2005.12.008

Ferro, S., Ricchelli, F., Monti, D., Mancini, G., and Jori, G. (2007). Efficient photoinactivation of methicillin-resistant Staphylococcus aureus by a novel porphyrin incorporated into a poly-cationic liposome. Int. J. Biochem. Cell Biol. 39 (5), 1026-1034. doi:10.1016/j.biocel.2007.02.001

Fila, G., Kasimova, K., Arenas, Y., Nakonieczna, J., Grinholc, M., Bielawski, K. P., et al. (2016). Murine model imitating chronic wound infections for evaluation of antimicrobial photodynamic therapy efficacy. Front. Microbiol. 7, 1258. doi:10.3389/fmicb.2016.01258

Fischer, D., Li, Y., Ahlemeyer, B., Krieglstein, J., and Kissel, T. (2003). In vitro cytotoxicity testing of polycations: influence of polymer structure on cell viability and hemolysis. Biomaterials 24 (7), 1121-1131. doi:10.1016/s0142-9612(02)00445-3

Frieri, M., Kumar, K., and Boutin, A. (2017). Antibiotic resistance. J. Infect. Public Health 10 (4), 369-378. doi:10.1016/j.jiph.2016.08.007

Gerhardt, S. A., Lewis, J. W., Kliger, D. S., Zhang, J. Z., and Simonis, U. (2003). Effect of micelles on oxygen-quenching processes of triplet-state parasubstituted tetraphenylporphyrin photosensitizers. J. Phys. Chem. A. 107 (15), 2763-2767. doi:10.1021/jp0270912

Hassan, D., Omolo, C. A., Fasiku, V. O., Elrashedy, A. A., Mocktar, C., Nkambule, B., et al. (2020). Formulation of $\mathrm{pH}$-responsive quatsomes from quaternary bicephalic surfactants and cholesterol for enhanced delivery of vancomycin against methicillin resistant Staphylococcus aureus. Pharmaceutics 12 (11), 1093. doi:10.3390/pharmaceutics12111093

Hernández Ramírez, R. E., Lijanova, I. V., Likhanova, N. V., Olivares Xometl, O., Hernández Herrera, A., Federico Chávez Alcalá, J., et al. (2020). Synthesis of PAMAM dendrimers with porphyrin core and functionalized periphery as templates of metal composite materials and their toxicity evaluation. Arab. J. Chem. 13 (1), 27-36. doi:10.1016/j.arabjc.2017.01.013

Kashef, N., Huang, Y.-Y., and Hamblin, M. (2017). Advances in antimicrobial photodynamic inactivation at the nanoscale. Nanophotonics 6 (5), 853-879. doi:10.1515/nanoph-2016-0189

Khan, R., Özkan, M., Khaligh, A., and Tuncel, D. (2019). Water-dispersible glycosylated poly(2,5'-thienylene)porphyrin-based nanoparticles for antibacterial photodynamic therapy. Photochem. Photobiol. Sci. 18 (5), 1147-1155. doi:10.1039/c8pp00470f

Khurana, R., Kakatkar, A. S., Chatterjee, S., Barooah, N., Kunwar, A., Bhasikuttan, A. C., et al. (2019). Supramolecular nanorods of (N-Methylpyridyl) porphyrin with captisol: effective photosensitizer for anti-bacterial and anti-tumor activities. Front. Chem. 7, 452. doi:10.3389/fchem.2019.00452

Kirar, S., Thakur, N. S., Laha, J. K., and Banerjee, U. C. (2019). Porphyrin functionalized gelatin nanoparticle-based biodegradable phototheranostics: potential tools for antimicrobial photodynamic therapy. ACS Appl. Bio Mater. 2 (10), 4202-4212. doi:10.1021/acsabm.9b00493

Kubát, P., Henke, P., Raya, R. K., Štěpánek, M., and Mosinger, J. (2019). Polystyrene and poly(ethylene glycol)-b-Poly( $\varepsilon$-caprolactone) nanoparticles with porphyrins: structure, size, and photooxidation properties. Langmuir 36 (1), 302-310. doi:10.1021/acs.langmuir.9b03468

Kumari, R., Khan, M. I., Bhowmick, S., Sinha, K. K., Das, N., and Das, P. (2017). Self-assembly of DNA-porphyrin hybrid molecules for the creation of antimicrobial nanonetwork. J. Photochem. Photobiol. B 172, 28-35. doi:10. 1016/j.jphotobiol.2017.05.010

Kumar, Y., Patil, B., Khaligh, A., Hadi, S. E., Uyar, T., and Tuncel, D. (2019). Novel supramolecular photocatalyst based on conjugation of cucurbit[7]uril to nonmetallated porphyrin for electrophotocatalytic hydrogen generation from water splitting. Chem CatChem 11 (13), 2994-2999. doi:10.1002/cctc.201900144

Lanzilotto, A., Kyropoulou, M., Constable, E. C., Housecroft, C. E., Meier, W. P., and Palivan, C. G. (2018). Porphyrin-polymer nanocompartments: singlet oxygen generation and antimicrobial activity. J. Biol. Inorg. Chem. 23 (1), 109-122. doi:10.1007/s00775-017-1514-8

Laxminarayan, R., Van Boeckel, T., Frost, I., Kariuki, S., Khan, E. A., Limmathurotsakul, D., et al. (2020). The lancet infectious diseases commission on antimicrobial resistance: 6 years later. Lancet Infect. Dis. 20 (4), e51-e60. doi:10.1016/S1473-3099(20)30003-7

Le Guern, F., Ouk, T. S., Ouk, C., Vanderesse, R., Champavier, Y., Pinault, E., et al. (2018). Lysine analogue of polymyxin B as a significant opportunity for photodynamic antimicrobial chemotherapy. ACS Med. Chem. Lett. 9 (1), 11-16. doi:10.1021/acsmedchemlett.7b00360 
Le Guern, F., Sol, V., Ouk, C., Arnoux, P., Frochot, C., and Ouk, T. S. (2017). Enhanced photobactericidal and targeting properties of a cationic porphyrin following the attachment of polymyxin B. Bioconjug. Chem. 28 (9), 2493-2506. doi:10.1021/acs.bioconjchem.7b00516

Li, C., Lin, F., Sun, W., Wu, F. G., Yang, H., Lv, R., et al. (2018). Self-assembled rose bengal-exopolysaccharide nanoparticles for improved photodynamic inactivation of bacteria by enhancing singlet oxygen generation directly in the solution. ACS Appl. Mater. Interfaces 10 (19), 16715-16722. doi:10.1021/ acsami.8b01545

Li, D., Fang, Y., and Zhang, X. (2020). Bacterial detection and elimination using a dual-functional porphyrin-based porous organic polymer with peroxidase-like and high near-infrared-light-enhanced antibacterial activity. ACS Appl. Mater. Interfaces 12 (8), 8989-8999. doi:10.1021/acsami.9b20102

Liu, K., Liu, Y., Yao, Y., Yuan, H., Wang, S., Wang, Z., et al. (2013). Supramolecular photosensitizers with enhanced antibacterial efficiency. Angew Chem. Int. Ed. Engl. 52 (32), 8285-8289. doi:10.1002/anie.201303387

Liu, M., Wang, L., Zheng, X., and Xie, Z. (2017). Zirconium-based nanoscale metalorganic framework/poly ( $\varepsilon$-caprolactone) mixed-matrix membranes as effective antimicrobials. ACS Appl. Mater. Interfaces 9 (47), 41512-41520. doi:10.1021/ acsami.7b15826

Mai, B., Gao, Y., Li, M., Wang, X., Zhang, K., Liu, Q., et al. (2017). Photodynamic antimicrobial chemotherapy for Staphylococcus aureus and multidrug-resistant bacterial burn infection in vitro and in vivo. Int. J. Nanomed. 12, 5915-5931. doi:10.2147/IJN.S138185

Mai, B., Jia, M., Liu, S., Sheng, Z., Li, M., Gao, Y., et al. (2020). Smart hydrogelbased DVDMS/bFGF nanohybrids for antibacterial phototherapy with multiple damaging sites and accelerated wound healing. ACS Appl. Mater. Interfaces 12 (9), 10156-10169. doi:10.1021/acsami.0c00298

Mbakidi, J. P., Herke, K., Alvès, S., Chaleix, V., Granet, R., Krausz, P., et al. (2013). Synthesis and photobiocidal properties of cationic porphyrin-grafted paper. Carbohydr. Polym. 91 (1), 333-338. doi:10.1016/j.carbpol.2012.08.013

Meng, S., Xu, Z., Hong, G., Zhao, L., Zhao, Z., Guo, J., et al. (2015). Synthesis, characterization and in vitro photodynamic antimicrobial activity of basic amino acid-porphyrin conjugates. Eur. J. Med. Chem. 92, 35-48. doi:10. 1016/j.ejmech.2014.12.029

Mima, E. G., Pavarina, A. C., Dovigo, L. N., Vergani, C. E., Costa, C. A., Kurachi, C., et al. (2010). Susceptibility of Candida albicans to photodynamic therapy in a murine model of oral candidosis. Oral Surg. Oral Med. Oral Pathol. Oral Radiol. Endod. 109 (3), 392-401. doi:10.1016/j.tripleo.2009.10.006

Moreira, A. L., Novaes, A. B., Grisi, M. F., Taba, M., Souza, S. L., Palioto, D. B., et al. (2015). Antimicrobial photodynamic therapy as an adjunct to non-surgical treatment of aggressive periodontitis: a split-mouth randomized controlled trial. J. Periodontol. 86 (3), 376-386. doi:10.1902/jop.2014.140392

Nam, W., Lim, M. H., Oh, S.-Y., Lee, J. H., Lee, H. J., Woo, S. K., et al. (2000). Remarkable anionic axial ligand effects of iron (III) porphyrin complexes on the catalytic oxygenations of hydrocarbons by $\mathrm{H}_{2} \mathrm{O}_{2}$ and the formation of oxoiron(IV) porphyrin intermediates by m-chloroperoxybenzoic acid. Angew Chem. Int. Ed. 39 (20), 3646-3649. doi:10.1002/1521-3773(20001016) 39:20<3646::aid-anie3646>3.0.co;2-q

Nicholson, F. (2020). "Infectious diseases: the role of the healthcare professional," in Clinical forensic medicine, Editor M. M. Stark (Berlin, Germany: Springer), 343-392.

Omolo, C. A., Kalhapure, R. S., Agrawal, N., Jadhav, M., Rambharose, S., Mocktar, C., et al. (2018). A hybrid of mPEG-b-PCL and G1-PEA dendrimer for enhancing delivery of antibiotics. J. Control Release 290, 112-128. doi:10. 1016/j.jconrel.2018.10.005

Omolo, C. A., Megrab, N. A., Kalhapure, R. S., Agrawal, N., Jadhav, M., Mocktar, C., et al. (2019). Liposomes with $\mathrm{pH}$ responsive 'on and off switches for targeted and intracellular delivery of antibiotics. J. Liposome Res. 31, 1-19. doi:10.1080/ 08982104.2019.1686517

Özkan, M., Kumar, Y., Keser, Y., Hadi, S. E., and Tuncel, D. (2019). Cucurbit[7] uril-Anchored porphyrin-based multifunctional molecular platform for photodynamic antimicrobial and cancer therapy. ACS Appl. Bio Mater. 2 (11), 4693-4697. doi:10.1021/acsabm.9b00763

O’Neill, J. (2014). “Antimicrobial resistance: tackling a crisis for the health and wealth of nations, in Review on antimicrobial resistance. London, United Kingdom.
Penon, O., Marín, M. J., Amabilino, D. B., Russell, D. A., and Pérez-García, L. (2016). Iron oxide nanoparticles functionalized with novel hydrophobic and hydrophilic porphyrins as potential agents for photodynamic therapy. J. Colloid Interface Sci. 462, 154-165. doi:10.1016/j.jcis.2015.09.060

Prasanth, C. S., Karunakaran, S. C., Paul, A. K., Kussovski, V., Mantareva, V., Ramaiah, D., et al. (2014). Antimicrobial photodynamic efficiency of novel cationic porphyrins towards periodontal gram-positive and gram-negative pathogenic bacteria. Photochem. Photobiol. 90 (3), 628-640. doi:10.1111/ php. 12198

Rice, L. B. (2012). Mechanisms of resistance and clinical relevance of resistance to $\beta$-lactams, glycopeptides, and fluoroquinolones. Mayo Clin. Proc. 87, 198. doi:10.1016/j.mayocp.2011.12.003

Shabangu, S. M., Babu, B., Soy, R. C., Oyim, J., Amuhaya, E., and Nyokong, T. (2020). Susceptibility of Staphylococcus aureus to porphyrin-silver nanoparticle mediated photodynamic antimicrobial chemotherapy. J. Lumin. 222, 117158. doi:10.1016/j.jlumin.2020.117158

Sigusch, B. W., Engelbrecht, M., Völpel, A., Holletschke, A., Pfister, W., and Schütze, J. (2010). Full-mouth antimicrobial photodynamic therapy in Fusobacterium nucleatum-infected periodontitis patients. J. Periodontol. 81 (7), 975-981. doi:10.1902/jop.2010.090246

Sigusch, B. W., Pfitzner, A., Albrecht, V., and Glockmann, E. (2005). Efficacy of photodynamic therapy on inflammatory signs and two selected periodontopathogenic species in a beagle dog model. J. Periodontol. 76 (7), 1100-1105. doi:10.1902/jop.2005.76.7.1100

Skwor, T. A., Klemm, S., Zhang, H., Schardt, B., Blaszczyk, S., and Bork, M. A. (2016). Photodynamic inactivation of methicillin-resistant Staphylococcus aureus and Escherichia coli: a metalloporphyrin comparison. J. Photochem. Photobiol. B, Biol. 165, 51-57. doi:10.1016/j.jphotobiol.2016.10.016

Sobotta, L., Skupin-Mrugalska, P., Piskorz, J., and Mielcarek, J. (2019) Porphyrinoid photosensitizers mediated photodynamic inactivation against bacteria. Eur. J. Med. Chem. 175, 72-106. doi:10.1016/j.ejmech.2019.04.057

Spagnul, C., Turner, L. C., Giuntini, F., Greenman, J., and Boyle, R. W. (2017). Synthesis and bactericidal properties of porphyrins immobilized in a polyacrylamide support: influence of metal complexation on photoactivity. J. Mater. Chem. B 5 (9), 1834-1845. doi:10.1039/c6tb03198f

Spiller, W., Kliesch, H., Wöhrle, D., Hackbarth, S., Röder, B., and Schnurpfeil, G. (1998). Singlet oxygen quantum yields of different photosensitizers in polar solvents and micellar solutions. J. Porphyr. Phthalocyanines 02 (02), 145-158. doi:10.1002/(sici)1099-1409(199803/04)2:2<145::aid-jpp60>3.0.co;2-2

Staegemann, M. H., Gitter, B., Dernedde, J., Kuehne, C., Haag, R., and Wiehe, A. (2017). Mannose-functionalized hyperbranched polyglycerol loaded with zinc porphyrin: investigation of the multivalency effect in antibacterial photodynamic therapy. Chem. Eur. J. 23 (16), 3918-3930. doi:10.1002/chem. 201605236

Stájer, A., Kajári, S., Gajdács, M., Musah-Eroje, A., and Baráth, Z. (2020). Utility of photodynamic therapy in dentistry: current concepts. Dent. J. 8 (2), 43. doi:10. 3390/dj8020043

Sułek, A., Pucelik, B., Kobielusz, M., Łabuz, P., Dubin, G., and Dąbrowski, J. M. (2019). Surface modification of nanocrystalline $\mathrm{TiO}_{2}$ materials with sulfonated porphyrins for visible light antimicrobial therapy. Catalysts 9 (10), 821. doi:10. 3390/catal9100821

Theuretzbacher, U., Outterson, K., Engel, A., and Karlén, A. (2020). The global preclinical antibacterial pipeline. Nat. Rev. Microbiol. 18 (5), 275-285. doi:10. 1038/s41579-019-0288-0

Vzorov, A. N., Dixon, D. W., Trommel, J. S., Marzilli, L. G., and Compans, R. W. (2002). Inactivation of human immunodeficiency virus type 1 by porphyrins. Antimicrob. Agents Chemother. 46 (12), 3917-3925. doi:10.1128/aac.46.12. 3917-3925.2002

Wang, D., Niu, L., Qiao, Z. Y., Cheng, D. B., Wang, J., Zhong, Y., et al. (2018). Synthesis of self-assembled porphyrin nanoparticle photosensitizers. ACS Nano. 12 (4), 3796-3803. doi:10.1021/acsnano.8b01010

Wang, Q., Chen, W., Zhang, Q., Ghiladi, R. A., and Wei, Q. (2018). Preparation of photodynamic P(MMA-co-MAA) composite nanofibers doped with MMT: a facile method for increasing antimicrobial efficiency. Appl. Surf. Sci. 457 247-255. doi:10.1016/j.apsusc.2018.06.041

Wang, Y., Liu, Y., Li, G., and Hao, J. (2014). Porphyrin-based honeycomb films and their antibacterial activity. Langmuir 30 (22), 6419-6426. doi:10.1021/la501244s 
Wei, L., Lu, J., Xu, H., Patel, A., Chen, Z. S., and Chen, G. (2015). Silver nanoparticles: synthesis, properties, and therapeutic applications. Drug Discov. Today 20 (5), 595-601. doi:10.1016/j.drudis.2014.11.014

WHO (2018). WHO Report on Surveillance of Antibiotic Consumption: 2016-2018 Early implementation. Geneva, Switzerland: World health oganisation.

WHO (2020). Antimicrobial resistance. Available at: https://www.who.int/newsroom/fact-sheets/detail/antimicrobial-resistance (Accessed October 13, 2020).

Wirotius, A.-L., Ibarboure, E., Scarpantonio, L., Schappacher, M., McClenaghan, N. D., and Deffieux, A. (2013). Hydrosoluble dendritic poly(ethylene oxide)s with zinc tetraphenylporphyrin branching points as photosensitizers. Polym. Chem. 4 (6), 1903-1912. doi:10.1039/c2py20936e

Xu, Z., Gao, Y., Meng, S., Yang, B., Pang, L., Wang, C., et al. (2016). Mechanism and in vivo Evaluation: photodynamic antibacterial chemotherapy of lysineporphyrin conjugate. Front. Microbiol. 7, 242. doi:10.3389/fmicb.2016.00242

Yuan, Y., Liu, Z. Q., Jin, H., Sun, S., Liu, T. J., Wang, X., et al. (2017). Photodynamic antimicrobial chemotherapy with the novel amino acid-porphyrin conjugate 4I: in vitro and in vivo studies. PLoS One 12 (5), e0176529. doi:10.1371/journal.pone.0176529

Zagami, R., Franco, D., Pipkin, J. D., Antle, V., De Plano, L., Patanè, S., et al. (2020). Sulfobutylether- $\beta$-cyclodextrin/5,10,15,20-tetrakis(1-methylpyridinium-4-yl) porphine nanoassemblies with sustained antimicrobial phototherapeutic action. Int. J. Pharm. 585, 119487. doi:10.1016/j.ijpharm.2020.119487

Zeina, B., Greenman, J., Purcell, W. M., and Das, B. (2001). Killing of cutaneous microbial species by photodynamic therapy. Br. J. Dermatol. 144 (2), 274-278. doi:10.1046/j.1365-2133.2001.04013.x

Zhang, G. D., Harada, A., Nishiyama, N., Jiang, D. L., Koyama, H., Aida, T., et al. (2003). Polyion complex micelles entrapping cationic dendrimer porphyrin: effective photosensitizer for photodynamic therapy of cancer. J. Control Release 93 (2), 141-150. doi:10.1016/j.jconrel.2003. 05.002

Zhao, Z. J., Xu, Z. P., Ma, Y. Y., Ma, J. D., and Hong, G. (2020). Photodynamic antimicrobial chemotherapy in mice with Pseudomonas aeruginosainfected wounds. PLoS One 15 (9), e0237851. doi:10.1371/journal.pone. 0237851

Zhu, Y., Chen, J., and Kaskel, S. (2020). Porphyrin-based metal-organic Frameworks for biomedical applications. Angew. Chem. Int. Ed. 60, 5010-5035. doi:10.1002/anie.201909880

Zoltan, T., Vargas, F., López, V., Chávez, V., Rivas, C., and Ramírez, Á. H. (2015). Influence of charge and metal coordination of meso-substituted porphyrins on bacterial photoinactivation. Spectrochim. Acta A Mol. Biomol. Spectrosc. 135, 747-756. doi:10.1016/j.saa.2014.07.053

Conflict of Interest: The authors declare that the research was conducted in the absence of any commercial or financial relationships that could be construed as a potential conflict of interest.

Copyright (c) 2021 Oyim, Omolo and Amuhaya. This is an open-access article distributed under the terms of the Creative Commons Attribution License (CC BY). The use, distribution or reproduction in other forums is permitted, provided the original author(s) and the copyright owner(s) are credited and that the original publication in this journal is cited, in accordance with accepted academic practice. No use, distribution or reproduction is permitted which does not comply with these terms. 